\title{
ESL Teachers' Questioning Technique in an Assessment for Learning Context: Promising or Problematic?
}

\author{
Sedigheh Abbasnasab Sardareh ${ }^{1}$, Mohd Rashid Mohd Saad ${ }^{1}$, Abdul Jalil Othman ${ }^{1} \&$ Rosalam Che $\mathrm{Me}^{2}$ \\ ${ }^{1}$ Faculty of Education, University of Malaya, Kuala Lumpur, Malaysia \\ ${ }^{2}$ Department of Design, Politecnico di Milano, Milan, Italy \\ Correspondence: Sedigheh Abbasnasab Sardareh, Faculty of Education, University of Malaya, 50603 Kuala \\ Lumpur, Malaysia. Tel: 601-7676-3252. E-mail: abbasnasab@gmail.com
}

Received: July 1, 2014 Accepted: August 2, 2014 Online Published: August 21, 2014

doi:10.5539/ies.v7n9p161 URL: http://dx.doi.org/10.5539/ies.v7n9p161

\begin{abstract}
As a crucial feature of assessment for learning (AfL), questioning technique plays an important part in student learning. In an AfL classroom, questioning technique is not merely a pedagogical tool to elicit evidence of students' understanding but also a means to improve their understanding. Effective classroom questioning underpins AfL; However, research into AfL raises significant doubt about the efficiency of teachers' questioning during AfL especially in Malaysian primary schools where AfL is still in its infancy. The current study illuminates the process of classroom questioning during AfL in a Malaysian primary school ESL context. This qualitative case study was conducted in a selected primary school around Selangor, Malaysia. Three ESL teachers teaching in the selected school took part in the study. In order to collect data, twenty periods of each teacher's classroom were observed. Then, interview was conducted with each individual teacher. Interviews and observations were tape-recorded verbatim and transcribed for further analysis. The results indicated that the low-cognitive level of questioning techniques and strategies were utilized by the three teachers. Many findings of this study point to the fact that teachers are still practicing teacher-centered syllabus. The results of the current study showed that the traditional concept of questioning was maintained and classroom questioning did not seem to fulfill the promise of enhancing learner autonomy which is the focus of AfL. The students were not encouraged to ask questions and engage in self-reflection. Many of them were silent oftentimes during classroom questioning and questions were usually answered by a specific group of students or the teachers themselves. Recommendations were made based on the results of the study.
\end{abstract}

Keywords: questioning technique, assessment for learning, ESL classrooms, student learning

\section{Introduction}

Students in an assessment for learning (AfL) classroom are exposed to the learning intentions at the very beginning of the learning and instruction process (Eisner, 2003; Haywood, Brown, \& Wingenfeld, 1990). They learn about the learning intentions and criteria for success as well as the scaffoldings they receive to achieve success (Vygotsky, 1978). In an AfL context, learners play an important role in their learning process (Hilgers, Hussey, \& Stitt-Bergh, 2000; Schön, 1995; Wang, 2010). They have continuous collaboration with their teacher and peer and consistently communicate their learning evidence with them. Therefore, they have an important part in assessing their own learning through self- and peer-assessment (Alexander, 2013; De Bruin \& Van Gog, 2012; Kostons, Van Gog, \& Paas, 2012; Metcalfe, 2009; Wiliam, 2011). However, many research works established the evidence that students fail to monitor and evaluate their own performance especially their self-assessments (Dunlosky \& Lipko, 2007; Dunlosky et al., 2002; Serra \& Metcalfe, 2009; Thiede et al., 2009). But, there are instructional techniques that seem to improve accuracy such as training and using standards to assess performance by means of modeling to student (Kostons et al., 2012) and a standard description of expected answers by teachers (Butler \& Winne, 1995; Lipko et al., 2009; Rawson \& Dunlosky, 2007).

When the criteria for success is established and students know what is expected of them, then in order to implement AfL effectively, teachers need to ask questions of their students to ensure their learning as well as their progress towards learning intentions. As a crucial feature of AfL, effective questioning technique plays an important part in student learning to enhance executive function ability to develop reasoning (Sachdeva,1996), challenge students' beliefs and background knowledge (Petty, 1998), and strengthen their arguments and 
propositions (James \& Baldwin, 1997) depending on the types of questions being asked (Ramsden, 2003). It is however important for teachers to avoid factual (Lorsch \& Ronkowski, 1982) but focus more on deep-learning level (Ramsden, 2003) type of questions. In an AfL classroom, questioning technique is not merely a pedagogical tool to elicit evidence of students' understanding but also a means to improve their understanding (Black, Harrison, Lee, Marshall, \& Wiliam, 2003). Minton (2005) for example suggests that "questioning does not come naturally to most people because novice teachers are used to thinking in terms of answers not questions" (p. 163). It needs to be stated at the outset that, Bloom's (1956) cognitive domain criteria is useful for designing questions.

Negative effects of poor rapport, peer and social pressure and closed ended questioning (see Fisher, Milne \& Bull, 2011; Milne et al., 2010) need to be avoided by classroom teachers and best practices can result in higherquality information gathered to assess students (Abbasnasab-Sardareh, \& Saad, 2013; Memon, Meissner, \& Fraser, 2011; Lamb, Orbach, Hershkowitz, Esplin, \& Horowitz, 2007). According to Cotton (1983) questions asked by teachers can be lower cognitive questions that include closed, knowledge, factual and recall questions. This will require students to give short responses based on what they have learned previously and higher cognitive questions that are also referred to as referential, interpretive, evaluative and open-ended questions and require students to create their own answers and help them promote higher order thinking skills and teachers need to encourage them explicitly (Scoboria \& Fisico, 2013). Studies have shown that questions teachers ask in the classroom are usually procedural and factual (Bartek, 2002; Brookfield, 1987; Myrick \& Yonge, 2002; Sellappah et al., 1998). These questions do not help students increase autonomy (Choi, Land, \& Turgeon, 2008; Cohen, 1994; Ismail \& Alexander, 2005; King, 1994; King \& Rosenshine, 1993; Rosenshine, Meister, \& Chapman, 1996) nor do they fulfill the other functions of questioning such as motivating students to think, developing their reflections and interest and encouraging students to ask questions (Brown \& Edmondson, 1985; Cooper, 2010).

Black and Wiliam (1998) claimed that not all question types improve learning. They added that when they pose a question, teachers usually look for a specific answer. So, students' future learning is inhibited and they lack opportunities to come up with their own answers. Teachers usually do not give students ample time to answer questions and they themselves respond to questions after a few seconds (Rowe, 1972). Research suggests that "good" or "rich" questions have the potential to diagnose students' misunderstandings (Wiliam, 1999), plan teaching (Burns, 2005), and provide opportunities for learners with mixed abilities (Sullivan \& Clarke, 1991). Wiliam (1999) described "rich questions" as questions that "reveal unintended conceptions" to provide a "window into thinking" (p. 16). He added that while these questions are difficult to construct, "they are essential as without them, there will be a number of students who manage to give all the right response, while having very different conceptions from those intended" (p. 16).

According to Sullivan and Liburn (2004) good questions have 3 features:

1) They require more than remembering a fact or reproducing a skill;

2) Students can learn by answering the questions and the teacher learns about each student from the attempt, and;

3) There may be several acceptable answers (p. 2).

Burns (2005) asserted that AfL requires students to clarify their responses to assist teachers in determining the next step in teaching and learning. That is to say, the focus should be mainly on Socratic methods of questioning that probe thinking at deep level. Socratic questioning means applying certain kinds of questioning such as discussion, clarification and probing questions (Yang, Newby, \& Bill, 2005). This kind of questioning is systematic, deep and focused on fundamental issues and concepts.

Probing encourages student-generated responses when they are explaining or correcting their responses and increases students' level of response (Cruickshank, Jenkins, \& Metcalf, 2009). The premise underlying probing questions is to guide students towards important aspects of the topic. However, directing the same question to another student or rewording the question might have negative effects and may lead to confusion amongst students (Cruickshank et al., 2009).

Students can also learn how to develop effective questions to improve their learning. Recently, students' questioning has received more attention because questioning techniques engage learners in critical reasoning and problem solving. Graesser and Olde (2003) maintained that "questions are asked when individuals are confronted with obstacles to goals, anomalous events, contradictions, discrepancies, salient contrasts, obvious gaps in knowledge, expectation violations and decisions that require discrimination among equally attractive alternatives" (p. 525). Therefore, students' questioning helps them to improve their thoughts and understanding 
and promote autonomy in their learning processes (Watts, Alsop, Gould, \& Walsh, 1997).

To understand how classroom questioning techniques facilitate teaching and learning milieu, Rowe (1974) conducted a study in elementary science classrooms in the U.S. to explore classroom discourse. He concluded that the mean time teachers wait after posing a question was only 0.9 seconds, and if there was no answer from the learner, the intervening was again 0.9 seconds. Therefore, to use questioning technique meaningfully, the time period should also be a guideline for teachers so as to avoid incomprehensible learning inputs.

Rowe (1974) argued that increasing wait time leads to the following changes in classroom discourse:

1) More longer and comprehensive answers.

2) More confident answers.

3) Challenging and improving other students' responses.

4) Students' failure to answer the question decreased.

5) Students offered more alternative explanations.

In other words, some of the failures in disseminating knowledge are not because of teachers' failure to single out students' comprehension but the way techniques are utilized and adopted is important as well. Confirming the finding of Rowe (1974), teachers in the KMOFAP project conducted by Black et al. (2003) found out that a wait time less than one second prevents students from participating in classroom discourse. Such a short wait time does not give students ample time to think and answer the questions. Teachers involved in KMOFAP projects agreed that they usually ask simple and closed questions requiring recall rather than deep thinking.

Sun (2012) explored the impact of ESL teachers' questioning techniques on teacher-learner interaction. In this survey, 73 students participated and two questionnaires (one on teacher and student interaction and the other on questioning techniques used by ESL teachers) were used for data collection. The results showed that students want their teachers to change their questioning strategies in order to develop a harmonious relationship between teacher and learners. The results also indicated that $2.6 \%$ of the students wish their teacher to make their wrong answers right, while $87.3 \%$ like their teacher to give them more time to think; $63.2 \%$ like to receive positive feedback even if they give the wrong answer; $78.4 \%$ responded that a specific group of students answer the questions, and $76.3 \%$ wish their teacher to give students of different ability levels the opportunity to answer questions. In sum, students desired an effective questioning environment to help them communicate with their teacher and answer the questions.

Effective classroom questioning underpins AfL; However, research into AfL raises significant doubt about the efficiency of teachers' questioning especially in Malaysian primary schools where AfL is still in its infancy (Black et al., 2003; Black \& Wiliam, 1998a; Brown \& Edmondson, 1985). Thus, the current study illuminates the process of classroom questioning during AfL in a Malaysian primary school ESL context. The results would help teachers and educators improve classroom questioning during AfL.

\section{Method}

In this study the researcher adopted the qualitative case study design to fully understand the phenomenon under investigation, collect rich data, and thoroughly answer the research questions. Merriam (1998) defines our approach well, "a case study design is employed to gain an in-depth understanding of the situation and meaning for those involved. This is consistent with other methodologist's views (Stake, 1995; Yin, 2003) because it promotes "understanding the dynamics present within single settings" (Eisenhardt, 1989, p. 533).The interest is in process rather than outcomes, in context rather than a specific variable, in discovery rather than confirmation" (p. 19). In other words, we need to view case studies as a powerful methodology that can be used in a rigorous, creative and wide-ranging variety of ways to advance education research. Unlike Yin (2003) who uses deductive positivism we adopt interpretivism approach (Denzin, 2001; Miles \& Huberman, 1994; Schwandt, 2000; Stake, 2005), in our data collection, analysis and interpretations.

The unit of analysis can be defined as "a phenomenon of some sort occurring in a bounded context" (Miles \& Huberman, 1994, p. 25). The selection of a single-case (Eisenhardt, 1989; Graebner \& Eisenhardt, 2004) was because they are unusually revelatory or extreme exemplars which are later revealed below. Also, we had deep access to the school and because the case offered a distinctive and extraordinary setting in which to observe the phenomenon under investigation. For data collection, the use of multiple data sources is justified which enhances our data credibility (Patton, 1990). Interviews from the primary data source in our single case study are a targeted, insightful and highly efficient means by which to collect rich, empirical data but we also admit that error which contaminates interview narratives especially in these retrospective narratives (Golden, 1992). 
Therefore, the use of interviews and direct observations employed in this study is justified.

\subsection{Research Site and Participants}

This study took place in a selected government primary school around Selangor, Malaysia. The school was selected using purposive sampling strategy. The selected school is among top ten percent school in the state of Selangor, Malaysia. The school focuses on the AfL implementations in its plan and teachers were highly encouraged to use the assessment data to improve teaching and learning processes. It should be mentioned that during the data collection, the AfL was only implemented in primary One and Two, this study focuses on Year One and Year Two classrooms (Malaysia, 2010, Ministry of Education, 2012). This school had two Year One and two Year Two classes. Three ESL teachers one teaching two Year One classes (Year One A \& B) and the other two teaching two Year Two classes (Year Two A \& B) participated in this study. The teachers' teaching tenure ranged from 8 to 10 years and they were willing to take part in the study. To protect the participating teachers' anonymity, pseudonyms were used. The Year One teacher is refered to as Devi, the Year Two A teacher is named Irwan, and the Year Two B is refered to as Izyan.

\subsection{Data Collection and Analysis}

In order to collect data, twenty periods of each teacher's classroom were observed. Then, interview was conducted with each individual teacher. Interviews and observations were tape-recorded and transcribed verbatim for further analysis. In the current study, the researcher applied Nvivo 10 software to analyze the data using the constant comparative method. In the first phase of data analysis that is called 'open coding' the researcher read through all the transcriptions to develop the codes. During the process of open coding, the data was broken apart in an analytical way which leads to a grounded conceptualization (Strauss, 1987). Many codes were developed in this phase.

In the second stage which is axial coding, the researcher put the codes into conceptual categories and made relationship between subcategories and categories to make the data manageable. Then, in the third phase, the core categories that have emerged from the axial coding helped the researcher to refine the interview questions and gain more relevant data from interviews, observations and documents. However, as the analysis progressed, the initial codes were reclassified and the emergent themes were reformulated to find the final categories and summarize the data collected during 4 months in the selected school.

\section{Results and Discussion}

Formative assessment (Black \& Wiliam, 1998; Daws \& Singh, 1996; Gearhart et al., 2006; Pellegrino, Chudowsky, \& Glaser, 2001) is deemed critical components for effective instructions. Informal questioning (Assessment Reform Group, 2002; Black, 2009; Jordan \& Putz, 2004; Moss, 2008), was a typical instructional and assessment strategy used by the participating teachers. The importance of our findings is that relative to formal formative assessment informal formative assessment, as shown by teachers' analysis, usually went unrecorded (Ruiz-Primo \& Furtak, 2006; 2007). Therefore, often times, informal formative assessment activities go unrecorded. However, our data showed that the teachers asked low-level cognitive questions and the main purpose of questioning was to check the students' knowledge and understanding, therefore the pattern of "a normal, ubiquitous part of all social interaction" (Jordan \& Putz, 2004, p. 346) revealed low-cognitive practices as can be seen during the in the Initiation, Response, Follow-up (IRF) (Sinclair \& Coulthard, 1975) and Initiation, Response, Evaluation (IRE) (Mehan, 1979) instructional dialogues below (Bellack, Kliebard, Hyman, \& Smith, 1966).

For example, Irwan, Year Two A teacher, usually showed his students a picture and asked them "what are these?" or "What can you see in the picture?" The students had to think and recall knowledge from their memory to answer the question. In the same way, Devi, Year One A \& B teacher mentioned that:

When we ask questions students need to recall what they have learned previously to answer the questions. So, we ask simple questions related to their previous knowledge to see whether or not they are able to understand what we have taught (Devi, Interview).

Therefore, by asking questions Devi triggered the students' prior knowledge to see if they could recall information. For instance, when she was teaching the students the topic of "Earth detective" she asked questions about what she had taught them the day before in order to check whether they could remember what they have learned or not.

\section{Extract 1}

T: Now rule number two "turn off the tap after you wash your hands". 
Ss: Hands

T: O.K first you turn on when you wash your hand. Then you use soap right? Do you still remember how to wash your hands?

Ss: Yes

Ss: No

T: O.K step number one: wet your hands. Step number two

$\mathrm{S}_{8}$ : Soap

T: Use soap. O.K step number three

$\mathrm{S}_{8}$ : You scrub the hands

$\mathrm{T}$ : Scrub between your

$\mathrm{S}_{8}$ : Fingers

T: Fingers. Then?

$\mathrm{S}_{8}$ : Rinse

T: Scrub behind *your* hand. After that

$\mathrm{S}_{8}$ : Wash your hands

$\mathrm{T}$ : Wash your hands. And lastly

$\mathrm{S}_{8}$ : Clean your hand or

T: Wipe

$\mathrm{S}_{3}$ : Wipe your hand

T: Wipe your hand using? Wipe your hands using?

$\mathrm{S}_{8}$ : Towel towel or tissue

$\mathrm{S}_{5}$ : Tissue

Some Ss: Towel

T: Using tissue or towel.

The triadic dialogues (IRF and IRE; Lemke, 1990) are not intrinsically good or bad, rather it leaves the door open for productive dialogic interactions (Scott, Mortimer, \& Aguiar, 2006). In the above dialogic interactions above, Devi was teaching the students some strategies for saving the planet earth. Then, in the next move (Bellack et al., 1966) she asked a question about the previous lesson to check the students' knowledge. She addressed the question to the whole class but only a few students tried to respond and this thus making this dialoging less effective and monotonous knowledge acquisition (Chin, 2006; 2007; Scott et al., 2006). Izyan, Year Two B teacher, mentioned that "we ask questions to see how far the students have achieved" (Izyan, Interview). For example, after teaching the topic of "parts of the body" she asked the students to name the human body parts. So, the students needed to recall what they have learned to respond to the question. Knowledge questions are good to assess students' ability to recall information but it is important to note that the key focus of AfL is to make students highly independent, therefore, teachers in an AfL classroom need to formulate strategic questions to make students reflect on their own learning and become the owners of their own learning.

This has devoured from academic domain self-regulation (Hogan, 1997) and does not support students' abilities to reason and reflect on their own learning (Bransford, Brown, \& Cocking, 1999). Further, in line with Black et al. (2003), Black and Wiliam (1998), and Brown and Edmondson (1985), the results of this study revealed that the teachers lack knowledge and understanding to practice effective questioning techniques that would foster autonomy as a social construct in the classroom and therefore need more training in this regard. The teachers need to ask more strategic questions to help students formulate their own responses, interact with each other and develop autonomy (Duschl, 2003; Duschl \& Osborne, 2002). Bell and Cowie (2001) proposed the assessment strategies cycles which can be followed in the classroom dialoging: collecting information, interpreting information, and acting-on/using the information collected and then clarify the learning expectations to the students (Ruiz-Primo et al., 2007; Sadler, 1989) to enhance quality and effectiveness of questioning.

According to Vygotsky (1978) when more knowledgeable peers in the community of practice guide learners to expand their understanding of the tools within the community, learners improve expertise and adopt a more 
participatory role within that community. As Sadler (1989) put it "learners should be able to understand and control the doing while it is happening" (p. 1). These statements emphasize the importance of learners' ability to monitor their own learning to improve autonomy which is the main focus of AfL.

Izyan found out that the best way to make classroom questioning more effective is through the use of visual aids. She stated that:

A good strategy to get the students motivated or to get them involved in classroom questioning is through using visual aids. If you use the television, just a simple slide show let's say you have simple story and then you have pictures to go along with the story you use that and they are very attentive and when you ask questions everybody wants to get involved and they can ask themselves about the question. Everybody wants to answer so yeah the most effective way that I can relate to is through using the television, using pictures or maybe the power point presentation (Izyan, Interview).

Izyan usually held language arts classes in the library because she could make use of the available facilities and teaching aids. At the beginning of a teaching session she took her students to the library and asked them to sit around the two big tables. Then she distributed a worksheet among the students that included pictures of some sea animals. Before giving instruction to the students on how to complete the task, Izyan started to show them the picture of sea animals and asked some questions. Extract 2 shows the dialogue between the teacher and the students.

\section{Extract 2}

T: Can dolphin live on land

$\mathrm{S}_{\mathrm{x}}$ : No

T: Then what happens?

$\mathrm{S}_{12}$ : Dies

T: What happens to Dolphin?

$\mathrm{S}_{12}$ : It needs water

$\mathrm{S}_{6}$ : Tak boleh nafas [Cannot breathe]

T: Cannot breathe.

In extract 2, the teacher was not asking high cognitive level questions and wanted the students to give specific answers to the questions. Moreover, since the students had previously learned the names of common sea animals, most of them were expected to answer the questions correctly. However, as can be seen in extract 2, only three students tried to answer the questions and the rest were silent. Overall, some students were always seen to be silent in the classroom.

Izyan addressed the question to the whole class. Those who knew the answer responded to the questions immediately and other students were not provided with the opportunity to give an answer. It was also evident that the teacher had a specific answer in mind because when $S_{x}$ and $S_{12}$ tried to answer the question, the teacher did not approve or reject their responses. But when $\mathrm{S}_{6}$ provided the desired response, the teacher immediately approved the answer.

Although the students were asked to work together, they did not have the opportunity to share the processes of learning ownership, collaborate with their peers and progress within the social safety of the peer culture. In fact, in an AfL classroom teachers need to give all students the opportunity to answer the questions so that they can improve expertise and become autonomous learners.

Approaching the questions to the whole class may decrease students' level of participation as indicated in extract 2. A good strategy is to call student's name for the answer and even if they give the wrong answer, guidance should be provided until they can give the correct answer with minimal assistance.

It was observed that most of the time questions were instantly answered by good students or by the teachers themselves. Izyan mentioned that:

Since my class is a mixed ability classroom, normally the very good one would answer first. I can say when I ask question, the very good one would answer first and the passive one would be quiet. You know sometimes we cannot be ambitious. As long as they get the knowledge we are satisfied. For good students we are ambitious we can give them so many input. For moderate and weak students we cannot be that ambitious so as long as they manage to obtain the learning objectives for that day it is ok and then we ask another student to answer (Izyan, 
Interview).

Izyan viewed that there was no need to call good students' name to answer the questions because whenever they knew the answer they responded immediately without putting up their hands. She did not expect too much from weak students and stated that:

Maybe they do not understand. When I call them and they give the wrong answer, I ask another student to respond to the question. Then I ask the weak student to repeat the correct answer. Although they do not know they can listen to their friend and repeat the answer (Izyan, Interview).

Devi emphasized the importance of classroom questioning and explained that effective questions give us feedback on students' learning. "When we ask question in the classroom students tend to talk. They should be able to think and give you an accurate answer so we can ensure their learning" (Devi, Interview). It was observed that most of the time only certain students answered the questions.

\section{Extract 3}

T: class what was the rule number four to save the earth? Do you remember?

$\mathrm{S}_{8}$ : Collect rain water to water the plants.

T: O.K Eh in this class ada Angel seorang je ke? Yang lain mana? [Is Angel the only student in this class? Others?]

Akif O.K tell me apa lagi peraturan lain Akif [Akif tell me another rule]

$\mathrm{S}_{15}$ : Turn off

$\mathrm{S}_{9}$ : Turn off the tap

T: turn off the tap | Turn off the tap, OK?

Akif who wants to help Akif

$\mathrm{S}_{8}$ : Yes, me

T: Turn off the tap when we when are not what?

$\mathrm{S}_{8}$ : When we are brushing our teeth

In extract 3, the teacher was asking the students to name the rules for saving the planet earth. Devi had taught them the rules at the beginning of the session. She asked the above question just to see if the students have learned the rules or not. As soon as the teacher posed the question $\mathrm{S}_{8}$ answered. $\mathrm{S}_{8}$ was an active and confident student who answered the teacher's questions more often.

In the next turn, the teacher invited the rest of the students to take an active role and respond to the question. But the students were observed to resist the teacher's expectations for participation. For instance, she called one of the students $\left(\mathrm{S}_{15}\right)$ to tell another rule for saving the earth. The student tried to answer but he could not remember the rule so the teacher asked other students to help $S_{15}$ to respond to the question. But as always it was $S_{8}$ who answered the question quickly.

In extract 3 , using questioning technique, Devi invited $\mathrm{S}_{15}$ to enter a more collaborative view of learning and encouraged him to extend identity towards a more central participant. However, she did not provide the student with guidance to direct him towards the answer and enough think time was not given so that the student could come up with the right answer and become a central participant. As extract 3 shows, $\mathrm{S}_{15}$ became less participatory and more peripheral when he could not give the full answer and the teacher directed the question to other students without waiting for him to give a complete answer to the question.

It was observed that in Devi's classrooms usually the students did not have enough time and opportunity to answer the questions. As Devi put it:

most of the time I do not have enough time to wait because I need to finish the syllabus ... depending on the time but sometimes we have to tell them the answer. Sometimes if a student gives me the wrong answer, I ask another student. When the student listens to the correct answer given by his/her friend then he knows he was wrong (Devi, Interview).

Several times, the researcher observed that Devi answered the questions herself without waiting for the students to respond. For example, extract 4 shows that while teaching the story "the tiny thimble", Devi asked the students to find a synonym for the word "tiny". But when a student gave the wrong answer, she herself responded to the question without guiding the student to give the correct answer or asking another student to 
give an answer. She rejected the answer given by $S_{12}$ and provided the students with the correct answer. Yet, in an AfL classroom teachers should handle students' wrong responses in order to increase the challenge and consequently the level of interaction among teacher-students and student-student in the classroom. The teacher could wait for the students to give possible responses to the questions and discuss among themselves to find the correct answer.

\section{Extract 4}

T: The tiny thimble

Ss: The tiny thimble

T: What is tiny? What is tiny? Who knows what is tiny?

$\mathrm{S}_{12}$ : Puteri [Princess]

T: Puteri? No

It is small. Tiny means small.

Questioning is a form of social interaction (Tierney \& Charland, 2007) and requires learners' active participation (Rogoff, 1990). Yet, the data showed that the students had rarely an opportunity to actively take part in classroom questioning.

Irwan accentuated the importance of questioning in fostering students' active participation. "When I ask questions, I expect my students to speak up and try to answer it rather than to keep quiet in the classroom" (Irwan, Interview). Irwan wanted the students to actively participate and answer the questions. In extract 5, the students were doing an activity in the activity book. The teacher addressed the question to one of the students and asked him to match one of the sentences to picture number one. Right away after posing the question, some students tried to give the answer but the teacher asked them to remain silent and called a particular student to respond to the question. When Irwan called a certain student to answer the question, other students who wanted to answer became less participatory. Extract 5 shows that the teacher invited that particular student $\left(\mathrm{S}_{5}\right)$ to extend his identity towards a more central participant, yet, when $\mathrm{S}_{5}$ gave the wrong answer, one of the most active students in the classroom $\left(\mathrm{S}_{11}\right)$ answered the question.

\section{Extract 5}

T: O.K Faiz tell me which one is picture number one?

Some students: Put the-

T: I asked Faiz. I do not ask others. Faiz which one is number one?

$\mathrm{S}_{5}$ : The machine turns the used cans into new cans

T: Ha? Wrong. That is wrong.

$\mathrm{S}_{11}$ : Teacher saya [Teacher, me?]

T: O.K Durga

$\mathrm{S}_{11}$ : Put the cans into the orange recycling bin

$\mathrm{T}$ : Yes. That is number one

As evident in Extract 5, instead of directing the student to give the correct answer, the teacher asked another student to answer the question. In other words, $\mathrm{S}_{5}$ was not provided with enough time to think and respond to the question and guidance was not given to direct the students towards the correct answer. Therefore, $\mathrm{S}_{5}$ did not develop a more central participatory role, whereas $S_{11}$ became more participatory. This is in line with Rowe (1974) as well as Black et al. (2003) findings that not enough wait time is allocated for the students to provide answers to questions and avoid teacher-centered learning.

The researcher also noticed that when the students did not understand the question or did not give the expected answer, Irwan relied on repeating and rephrasing the question. As he mentioned:

Maybe they do not understand what we are asking for so we have to simplify the questions. Sometimes we have to understand the way they are thinking so we can use simpler way of asking questions to help them provide the answer. I have to accept whatever they reply but then I tell them this is not the answer that I want so maybe when we pose the same question in a different way, they can give the correct answer (Irwan, Interview).

In extract 6, the teacher was teaching the topic of recycling. First he asked the students to read the passage in the textbook entitled "A Day in the Life of a Recycled Can" and after that he asked questions. 


\section{Extract 6}

T: O.K very good. So what happened first? What happened first? Agus. Who is Agus? What did he do? What happened?

Agus is a name of a person maybe a boy. So the boy drank using um...Maybe drank coke for example and then what happened? Agus rinses me.

O.K the workers will put the tin can into the machine. And what did the machine do?

Ss: The machine turns me and my friends into new cans again.

T: O.K so is it the same tin? Is it a new same can? It goes back, recycling and then becomes the same can all right. O.K now take out your activity book.

As can be seen in extract 6 , in the first instance, the teacher asked "what happened first?" then he repeated the question and raised it in different ways. Literature shows that repeating and rewording questions may lead to students' confusion and lower levels of participation (Cruickshank et al., 2009). Extract 6 also shows that when the teacher repeated and reworded the questions, the response rate decreased and it was the teacher himself who responded to the questions without waiting for the students to provide an answer.

It was observed that the other two teachers, Devi and Izyan, kept repeating a question several times or rephrased it. However, the teachers did not give the students enough time to think and give the correct answer. Also, they did not build on their responses in order to direct them towards the correct answer.

As mentioned in passing, the teachers also asked questions of their students using worksheets. It was observed that they used worksheets at the end of each instructional period in order to assess the students' understanding. The teachers considered worksheets to be a form of self-assessment as well as a source of learning.

For the students, worksheet fitted within their cultural narratives of tests rather than learning. Connecting learning with this cultural narrative of test created a conflict for the students who resolved it by not actively engaging in the AfL practice of classroom questioning and they were observed to complete worksheets individually without demur.

\section{Conclusion and Recommendation}

Many findings of this study point to the fact that all three teachers are still practicing teacher-centred syllabus. The findings of the present study support the findings of Sun (2012) which revealed that a change in classroom questioning is needed to build a harmonious relationship between teacher and students and help learners become independent. Moreover, teachers need to be aware of structuring their questioning episodes and ask effective questions in their classrooms. These findings highlight the importance of developing an effective question progression prior to the class in increasing classroom interaction and enhancing learner autonomy.

Identity in an autonomous learner is a continual social interaction that is identified by self-monitoring of the interaction patterns in the classroom. Questioning patterns of participation should be designed in a way that help students become co-constructors of knowledge by sharing the ownership of their learning within the community of practice. But the results of the current study showed that the traditional concept of questioning was maintained and classroom questioning did not seem to fulfill the promise of enhancing learner autonomy. The students were not encouraged to ask questions and engage in self-reflection. Many of them were silent oftentimes during classroom questioning and questions were usually answered by a specific group of students or the teachers themselves.

Based on the results, the researchers recommend the following steps for effective classroom questioning:

1) Preparing a series of questions (question progression): It is important to design questions based on the purpose they serve. While designing questions, teachers also need to consider the cognitive level they want their students to be thinking. It would be effective to start with knowledge and comprehension questions, then build on these questions and ask higher level cognitive questions (Use Bloom's classification of question types). One good strategy is to ask students design questions at different levels. This strategy leads to student participation and helps teachers assess student two times; while developing the questions and while answering them.

2) Posing the question and selecting a respondent: Pose the question and make sure that all of the students have the opportunity to answer the question (especially in populated classes). Having a seating chart may help teachers to track the number of questions answered by each student.

3) Prompting students' responses: Students need enough time to process the question and find the answer. So, Depending on the level of questions, teachers should provide students with enough wait time to come up with 
their answer.

4) Processing and building on students' responses: Teachers should not put down students responses and build on their wrong answers and guide them towards the correct answer by giving clues or asking prompt questions.

5) Promoting student participation: Each and every student should get involve in classroom questioning. Giving feedback to student response may help teachers understand how they are thinking so teachers can build on their responses and guide them towards the correct answer. Socratic method of questioning can increase students level of participation in classroom questioning. Teacher poses a question to start the lesson then students discuss among themselves and develop questions as they think about the topic and teacher can ask follow-up questions to continue the lesson.

6) Reflecting on classroom questioning: Teachers can audiotape a lesson and listen back at the questions and students' responses, reflect on their questioning and figure out how they can ask more effective questions.

\section{Acknowledgements}

The authors thank all participants in this study for their kind cooperation.

\section{References}

Abbasnasab-Sardareh, S., \& Saad, M. R. M. (2013). Malaysian Primary School ESL teachers. Questions during Assessment for Learning. English Language Teaching, 6(8), 1-9. http://dx.doi.org/10.5539/elt.v6n8p1

Alexander, P. A. (2013). Calibration: What is it and why it matters? An introduction to the special issue on calibrating calibration. Learning and Instruction, 24, 1-3. http://dx.doi.org/10.1016/j.learninstruc.2012.10.003

Assessment Reform Group. (2002). Assessment for learning: 10 principles. Research based principles to guide classroom practice. Retrieved from http://www.assessment-reform-group.org.uk/CIE3.pdf

Bartek, M. M. (2002). Paving the road to critical thinking. Understanding Our Gifted, 14(4), 10-12.

Bell, B., \& Cowie, B. (2001). Formative assessment and science education. Dordrecht, NL: Kluwer.

Bellack, A. A., Kliebard, H. M., Hyman, R. T., \& Smith, F. L. (1966). The language of the classroom. New York, NY: Teachers College Press.

Black, P. (2009). From frequent testing to interactive dialogue: Diversity and challenge. Guest's editor introduction. Journal of Multidisciplinary Evaluation, 6(12), iii-vi.

Black, P., Harrison, C., Lee, C., Marshall, B., \& Wiliam, D. (2003). Assessment for learning: Putting it into practice. Buckingham, UK: Open University Press.

Black, P., \& Wiliam, D. (1998). Assessment and classroom learning. Assessment in Education: Principles, Policy and Practice, 5(1), 7-74. http://dx.doi.org/10.1080/0969595980050102

Bloom, B. S. (1956). Taxonomy of educational objectives: The classification of educational goals, Handbook I: cognitive domain. New York, NY: David Mckay.

Bransford, J., Brown, A., \& Cocking, R. (1999). How people learn: Brain, mind, experience and school. Washington, DC: National Academy Press.

Brookfield, S. D. (1987). Developing Critical Thinkers. Challenging Adults to Explore Ways of Thinking and Acting. San Francisco, CA: Jossey-Bass Publishers.

Brown, G. A., \& Edmondson, R. (1985). Asking questions. In E. C. Wragg (Ed.), Classroom teaching skills (pp. 97-120). London, UK: Croom Helm.

Burns, M. (2005). Looking at how students reason. Educational Leadership, 63(3), 26-31.

Butler, D. L., \& Winne, P. H. (1995). Feedback and self-regulated learning: A theoretical synthesis. Review of Educational Research, 65, 245-281. http://dx.doi.org/10.3102/00346543065003245

Chin, C. (2006). Classroom interaction in science: Teacher questioning and feedback to students' responses. International Journal of Science Education, 28(11), 1315-1346. http://dx.doi.org/10.1080/09500690600621100

Chin, C. (2007). Teacher questioning in science classrooms: Approaches that stimulate productive thinking. Journal of Research in Science Teaching, 44(6), 815-843. http://dx.doi.org/10.1002/tea.20171

Choi, I., Land, S. M., \& Turgeon, A. (2008). Instructor modeling and online guidance for peer questioning during 
online discussion. Journal of Educational Technology Systems, 36(3), 255-275. http://dx.doi.org/10.2190/ET.36.3.c

Cohen, E. G. (1994). Restructuring the classroom: Conditions for productive small groups. Review of Educational Research, 64, 1-35. http://dx.doi.org/10.3102/00346543064001001

Cooper, R. (2010). Those who can, teach (12th ed.). Boston, MA: Wadsworth Cengage Learning.

Cruickshank, D., Jenkins, D., \& Metcalf, K. (2009). The act of teaching (5th ed.). New York, NY: McGraw-Hill.

Daws, N., \& Singh, B. (1996). Formative assessment: To what extent is its potential to enhance pupils' science being realized? School Science Review, 77(281), 93-100.

De Bruin, A., \& Van Gog, T. (2012). Improving self-monitoring and self-regulation: from cognitive psychology to the classroom. Learning and Instruction, 22, 245-252. http://dx.doi.org/10.1016/j.learninstruc.2012.01.003

Denzin, N. K. (2001). Interpretive interactionism. Thousand Oaks, CA: Sage.

Dunlosky, J., \& Lipko, A. R. (2007). Metacomprehension: A brief history and how to improve its accuracy. $\begin{array}{lllll}\text { Current Directions in Psychological 228-232. } & \text { Science, }\end{array}$ http://dx.doi.org/10.1111/j.1467-8721.2007.00509.x

Dunlosky, J., Rawson, K., \& McDonald, S. (2002). Influence of practice tests on the accuracy of predicting memory performance for paired associates, sentences, and text material. In T. Perfect, \& B. Schwartz (Eds.), Applied metacognition (pp. 68-92). Cambridge, UK: Cambridge University Press. http://dx.doi.org/10.1017/CBO9780511489976.005

Duschl, R. A. (2003). Assessment of inquiry. In J. M. Atkin, \& J. E. Coffey (Eds.), Everyday assessment in the science classroom (pp. 41-59). Arlington,VA: National Science Teachers Association Press.

Duschl, R. A., \& Osborne, J. (2002). Supporting and promoting argumentation in science education. Studies in Science Education, 38, 39-72. http://dx.doi.org/10.1080/03057260208560187

Eisenhardt, K. M. (1989). Building theories from case study research. Academy of Management Review, 14(4), 532-550.

Eisner, E. W. (2003). Questionable assumptions about schooling. Phi Delta Kappan, 84(9), 648-657.

Fisher, R. P., Milne, B. A., \& Bull, R. (2011). Interviewing cooperative witnesses. Current Directions in Psychological Science, 20, 16-19. http://dx.doi.org/10.1177/0963721410396826

Gearhart, M., Nagashima, S., Pfotenhauer, J., Clark, S., Schwab, C., Vendlinsky, T., . . Herman, J. (2006). Developing expertise with classroom assessment in K-12 science: Learning to interpret student work. Interim findings from a 2-year study. Educational Assessment, 11(3-4), 237-263.

Golden, B. R. (1992). The past is the past-Or is it? The use of retrospective accounts as indicators of past strategy. Academy of Management Journal, 35(4), 848-860. http://dx.doi.org/10.2307/256318

Graebner, M. E., \& Eisenhardt, K. M. (2004). The seller's side of the story: Acquisition as courtship and governance syndicate in entrepreneurial firms. Administrative Science Quarterly, 49(3), 366-403.

Graesser, A., \& Olde, B. (2003). How does one know whether a person understands a device? The quality of the questions the person asks when the device breaks down. Journal of Educational Psychology, 95, 524-536. http://dx.doi.org/10.1037/0022-0663.95.3.524

Haywood, H. C., Brown, A. L., \& Wingenfeld, S. (1990). Dynamic approaches to psycho-educational assessment. School Psychology Review, 19(4), 411-422.

Hilgers, T. L., Hussey, E. L., \& Stitt-Bergh, M. (2000). The case for prompted self-assessment in the writing classroom. In J. B. Smith, \& K. B. Yancey (Eds.), Self-assessment and development in writing: A collaborative inquiry (pp. 1-24). Creskill, NJ: Hampton Press.

Hogan, K. (1997). Scaffolding: A powerful toll in social constructivist classrooms. In K. Hogan, \& M. Pressley (Eds.), Scaffolding student learning. Instructional approaches and issues (pp. 1-5). Cambridge, MA: Brookline Books.

Ismail, H., \& Alexander, J. (2005). Learning within scripted and non-scripted peer-tutoring session: The Malaysian context. Journal of Educational Research, 99, 67-77. http://dx.doi.org/10.3200/JOER.99.2.67-77

James, R., \& Baldwin, G., (1997). Tutoring and Demonstrating: A Guide for the University of Melbourne. Centre 
for the Study of Higher Education, University of Melbourne, Australia.

Jordan, B., \& Putz, P. (2004). Assessment as practice: Notes on measures, tests, and targets. Human Organization, 63, 346-358.

King, A. (1994). Guiding knowledge construction in the classroom: Effects of teaching children how to question and how to explain. American Educational Research Journal, 31(2), 338-368. http://dx.doi.org/10.3102/00028312031002338

King, A., \& Rosenshine, B. (1993). Effects of guided cooperative questioning on children's knowledge $\begin{array}{lllll}\text { construction. Journal of Experimental } & \text { Education, }\end{array}$ http://dx.doi.org/10.1080/00220973.1993.9943857

Kostons, D., Van Gog, T., \& Paas, F. (2012). Training self-assessment and task-selection skills: A cognitive approach to improving self-regulated learning. Learning and Instruction, 22, 121-132. http://dx.doi.org/10.1016/j.learninstruc.2011.08.004

Lamb, M. E., Orbach, Y., Hershkowitz, I., Esplin, P., \& Horowitz, D. (2007). A structured forensic interview protocol improves the quality and informativeness of investigative interviews with children: A review of research using the NICHD Investigative Interview Protocol. Child Abuse and Neglect, 31, 1201-1231. http://dx.doi.org/10.1016/j.chiabu.2007.03.021

Lemke, J. L. (1990). Talking science: Language, learning and values. Norwoord, NJ: Ablex.

Lipko, A. R., Dunlosky, J., Hartwig, M. K., Rawson, K. A., Swan, K., \& Cook, D. (2009). Using standards to improve middle-school students' accuracy at evaluating the quality of their recall. Journal of Experimental Psychology: Applied, 15, 307-318. http://dx.doi.org/10.1037/a0017599

Lorsch, N., \& Ronkowski, S. (1982). Teaching Tips for TA's: Effective Questioning Enhances Student Learning. Instructional Development, University of California, Santa Barbara.

Malaysia. (2010). Tenth Malaysia Plan 2011-2015. Economic Planning Unit, Prime Minister's Department, Putrajaya.

Mehan, H. (1979). Learning lessons: Social organization in the classroom. Cambridge, MA: Harvard University Press. http://dx.doi.org/10.4159/harvard.9780674420106

Memon, A., Meissner, C. A., \& Fraser, J. (2011). The cognitive interview: A meta-analytic review and study space analysis of the past 25 years. Psychology, Public Policy, and Law, 16, 340-372. http://dx.doi.org/10.1037/a0020518

Merriam, S. B. (1998). Qualitative research and case study applications in education. San Francisco, CA: Jossey-Bass.

Metcalfe, J. (2009). Metacognitive judgments and control of study. Current Directions in Psychological Science, 18, 159-163. http://dx.doi.org/10.1111/j.1467-8721.2009.01628.x

Miles, M. B., \& Huberman, A. M. (1994). Qualitative data analysis: A sourcebook of new methods. Beverly Hills, CA: Sage.

Milne, R., Poyser, S., Williamson, T., \& Savage, S. (2010). Miscarriages of justice: What can we learn? In J. Adler, \& J. Gray (Eds.), Forensic psychology: Concepts, debates and practice (17-37). Cullompton, UK: Willan Publishing.

Ministry of Education. (2012). Preliminary report: Malaysia education blueprint 2013-2025. Retrieved from http://www.moe.govt.my/userfiles/file/PPP

Minton, D. (2005). Teaching Skills in Further \& Adult Education (3nd ed.). London, UK: Thomson Learning.

Moss, P. A. (2008). Sociocultural implications for the practice of assessment I: Classroom assessment. In P. A. Moss, D. Pullin, J. P. Gee, E. H. Haertel, \& L. J. Young (Eds.), Assessment, equity, and opportunity to learn. New York, NY: Cambridge University Press.

Myrick, F., \& Yonge, O. (2002). Preceptor questioning and student critical thinking. Journal of Professional Learning, 18(3), 176-181. http://dx.doi.org/10.1053/jpnu.2002.124485

Patton, M. Q. (1990). Qualitative evaluation and research methods. Thousand Oaks, CA: Sage.

Pellegrino, J. W., Chudowsky, N., \& Glaser, R. (2001). Knowing what students know: The science and design of educational assessment. Washington, DC: National Academies Press. 
Petty, G. (1998). Teaching Today: A Practical Guide (2nd ed.). Cheltenham, UK: Nelson Thornes.

Ramsden, P. (2003). Learning to Teach in Higher Education (2nd ed.). London, UK: Routledge Falmer.

Rawson, K., \& Dunlosky, J. (2007). Improving students' self-evaluation of learning for key concepts in textbook materials. European Journal of Cognitive Psychology, 19, 559-579. http://dx.doi.org/10.1080/09541440701326022

Rogoff, B. (1990). Apprenticeship in thinking: Cognitive development in social context. New York, NY: Oxford University Press.

Rosenshine, B., Meister, C., \& Chapman, S. (1996). Teaching students to generate questions: A review of the intervention studies. Review of Educational Research, 66(2), 181-221. http://dx.doi.org/10.3102/00346543066002181

Rowe, M. B. (1972, April). Wait-time and rewards as instructional variables, their influence in language, logic and fate control. Paper presented at the National Association for Research in Science Teaching, Chicago, IL.

Rowe, M. B. (1974). Relation of wait-time and rewards to the development of language, logic, and fate control: Part II-Rewards. Journal of Research in Science Teaching, 11(4), 291-308. http://dx.doi.org/10.1002/tea.3660110403

Ruiz-Primo, M. A., \& Furtak, E. M. (2006). Informal formative assessment and scientific inquiry: Exploring teachers' practices and student learning. Educational Assessment, 11(3-4), 205-235.

Ruiz-Primo, M. A., \& Furtak, E. M. (2007). Exploring teachers' informal formative assessment practices and students' understanding in the context of scientific inquiry. Journal of Research in Science Teaching, 44(1), 57-84. http://dx.doi.org/10.1002/tea.20163

Sachdeva, A. K. (1996). Use of effective questioning to enhance the cognitive abilities of students. Journal of Cancer Educ., 11, 17-124.

Sadler, D. R. (1989). Formative assessment and the design of instructional strategies. Instructional Science, 18, 119-144. http://dx.doi.org/10.1007/BF00117714

Schön, D. A. (1995). Causality and casual inference in the study of organizations. In R. F. Goodman, \& W. R. Fisher (Eds.), Rethinking knowledge: Reflections across the disciplines (pp. 69-103). Albany, NY: SUNY Press.

Schwandt, T. A. (2000). Three epistemological stances for qualitative inquiry: Interpretivism, hermeneutics and social constructionism. In N. K. Denzin, \& Y. S. Lincoln (Eds.), Handbook of qualitative research (2nd ed.). Thousand Oaks, CA: Sage.

Scoboria, A., \& Fisico, S. (2013). Encouraging and clarifying 'don't know' responses enhances interview quality. Journal of Experimental Psychology: Applied, 19, 72-82. http://dx.doi.org/10.1037/a0032067

Scott, P. H., Mortimer, E. F., \& Aguiar, O. G. (2006). The tension between authoritative and dialogic discourse: A fundamental characteristic of meaning making interactions in high school science lessons. Cognition and Instruction, 20, 399-484.

Sellappah, S., Hussey, T., Blackmore, A. M., \& McMurray, A. (1998). The use of questioning strategies by

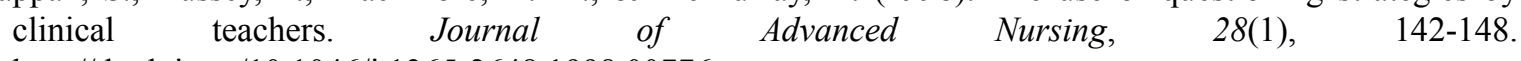
http://dx.doi.org/10.1046/j.1365-2648.1998.00776.x

Serra, M. J., \& Metcalfe, J. (2009). Effective implementation of metacognition. In D. J. Hacker, J. Dunlosky, \& A. C. Graesser (Eds.), Handbook of metacognition and education (pp. 278-298). New York, NY: Routledge.

Sinclair, J. M., \& Coulthard, M. (1975). Towards an analysis of discourse: The English used by teachers and pupils. London, UK: Oxford University Press.

Stake, R. E. (1995). The art of case study research. Thousand Oaks, CA: Sage.

Stake, R. E. (2005). Qualitative case studies. In N. K. Denzin, \& Y. S. Lincoln (Eds.), The Sage handbook of qualitative research (3rd ed., pp. 433-466). Thousand Oaks, CA: Sage.

Strauss, A. (1987). Qualitative analysis for social scientists. New York, NY: Cambridge University Press. http://dx.doi.org/10.1017/CBO9780511557842

Sullivan, P., \& Clarke, D. (1991). Catering to all abilities through "good" questions. The Arithmetic Teacher, 
39(2), 14-18.

Sullivan, P., \& Liburn, P. (2004). Open-ended math activities: Using "good" questions to enhance learning in mathematics. South Melbourne, VIC: Oxford University Press.

Sun, Z. (2012). An empirical study on new teacher-student relationship and questioning strategies in ESL classroom. English Language Teaching, 5(7), 175-183. http://dx.doi.org/10.5539/elt.v5n7p175

Thiede, K. W., Griffin, T. D., Wiley, J., \& Redford, J. S. (2009). Metacognitive monitoring during and after reading. In D. J. Hacker, J. Dunlosky, \& A. C. Graesser (Eds.), Handbook of metacognition and self-regulated learning (pp. 85-106). Mahwah, NJ: Erlbaum.

Tierney, R., \& Charland, J. (2007, April). Stocks and prospects: Research on formative assessment in secondary classrooms. Paper presented at the annual meeting of the American Educational Research Association, Chicago, IL.

Vygotsky, L. S. (1978). Mind in society: The development of higher psychological process. Cambridge, MA: Harvard University Press.

Wang, T. H. (2010). Web-based dynamic assessment: Taking assessment as teaching and learning strategy for improving students' e-Learning effectiveness. Computers \& Education, 54(4), 1157-1166. http://dx.doi.org/10.1016/j.compedu.2009.11.001

Watts, M., Alsop, S., Gould, G., \& Walsh, A. (1997). Prompting teachers' constructive reflection: Pupils' questions as critical incidents. International Journal of Science Education, 19(9), 1025-1037. http://dx.doi.org/10.1080/0950069970190903

Wiliam, D. (1999, May). A template for computer-aided diagnostic analyses of test outcome data. Paper presented at 25th annual conference of the International Association for Educational Assessment held at Bled, Slovenia. London, UK: King's College London School of Education.

Wiliam, D. (2011). What is assessment for learning? Studies in Educational Evaluation, 37(1), 3-14. http://dx.doi.org/10.1016/j.stueduc.2011.03.001

Yang, Y. C., Newby, T. J., \& Bill, R. L. (2005). Using Socratic questioning to promote critical thinking through asynchronous discussion forums in distance learning environment. The American Journal of Distance Education, 19(3), 163-181. http://dx.doi.org/10.1207/s15389286ajde1903_4

Yin, R. (2003). Applications of case study research. London, UK: Sage.

\section{Copyrights}

Copyright for this article is retained by the author(s), with first publication rights granted to the journal.

This is an open-access article distributed under the terms and conditions of the Creative Commons Attribution license (http://creativecommons.org/licenses/by/3.0/). 